Sains Malaysiana 51(1)(2022): 39-50

http://doi.org/10.17576/jsm-2022-5101-04

\title{
Population Structure of Indian Mackerel (Rastrelliger kanagurta) in Java and Bali Island, Indonesia Inferred from Otolith Shape
}

(Struktur Populasi Ikan Borek India (Rastrelliger kanagurta) di Jawa dan Kepulauan Bali, Indonesia diperoleh daripada Bentuk Otolit)

ARIEF WuJd**, HAN JU Kim \& ChUl WoOng OH

\section{ABSTRACT}

The Indian mackerel, Rastrelliger kanagurta, is a commercially important resource across Indonesia's archipelagic waters. Despite its essential role in the fisheries industry, information regarding its population structures for management purposes is still limited. The present study investigates the variability of otolith shape as an efficient tool for stock discrimination. A total of 159 pairs of sagittal otolith were sampled at four localities along the southern Java-Bali coastal waters. Otolith outline was modeled by using Wavelet coefficients and was compared between localities using ANOVA-like permutation test, Canonical Analysis of Principal Coordinates (CAP), and classification test performed using linear discriminant analysis. The results showed significant differences in the shape of otolith between populations, reflected explicitly in the morphological feature of the excisura major. The differences in otolith shape were examined from all localities (ANOVA-like, $p<0.001$, and CAP $p>0.05$ ), except those otoliths between Palabuhanratu and Pacitan, thus, a mixed stock may occur in these two locations. These findings were also confirmed by the low classification success rate using LDA 44.26\%. These results suggested that at least two distinct stocks potentially contributed to the fishery, impacting species management and conservation.

Keywords: Otolith morphology; Rastrelliger kanagurta; shapeR; stock identification; Wavelet transformation

\section{ABSTRAK}

Ikan borek India, Rastrelliger kanagurta, adalah sumber ikan komersial yang penting di seluruh perairan kepulauan Indonesia. Walaupun mempunyai kepentingan ekonomi yang tinggi dalam industri perikanan, maklumat struktur populasinya untuk tujuan pengurusan masih terhad. Penyelidikan ini mengkaji kebolehubahan bentuk otolit sebagai kaedah yang cekap untuk menilai struktur stok ikan. Sebanyak 159 pasang sagital otolit diambil dari empat kawasan di sepanjang perairan pantai selatan Jawa dan Bali. Garis besar otolit dimodelkan menggunakan pekali Wavelet dan dibandingkan antara lokasi dengan ujian ANOVA dengan permutasi, Analisis Kanonikal Koordinat Utama (CAP) dan pengelompokan dilakukan dengan menggunakan analisis diskriminan linear. Hasil kajian menunjukkan bahawa terdapat perbezaan yang signifikan dalam bentuk otolith antara populasi, terutama dalam pencirian morfologi pada bahagian eksikura major. Perbezaan signifikan diperoleh untuk bentuk otolit dari semua kawasan (ANOVA p $<0.001$ dan CAP p>0.05), kecuali otolit antara Palabuhanratu dan Pacitan. Ini mungkin disebabkan oleh terdapat stok campuran yang berlaku di kawasan tersebut. Penemuan ini juga disahkan oleh kadar kejayaan pengelasan yang rendah menggunakan LDA 44.26\%. Hasil ini menunjukkan bahawa sekurang-kurangnya dua stok berbeza berpotensi menyumbang kepada perikanan yang dapat memberi implikasi kepada pengurusan dan pemuliharaan spesies ikan ini.

Kata kunci: BentukR; morfologi otolit; pengenalpastian stok; penjelmaan Wavelet; Rastrelliger kanagurta

\section{INTRODUCTION}

The Indian mackerel, Rastrelliger kanagurta, is a highly migratory epipelagic species that preys on phytoplankton and zooplankton (Das et al. 2016; Hulkoti et al. 2013). Its distribution broadly ranged along the region of Indo-
Pacific, primarily from Southern Africa, India, Indo-Malay Islands, Northern Australia up to Indo-Pacific islands, off eastern China, and Ryukyu Islands (Collette \& Nauen 1983). It is highly productive in producing eggs with the size of maturity ranging between 18 and $26 \mathrm{~cm}$ for females 
(Arrafi et al. 2016; Hariati \& Fauzi 2011; Oktaviani et al. 2014) and has a maximum age around 5 and 6 years (Arrafi et al. 2016).

In Indonesia, the species also play an important role in the fishery industries contributing to small-scaled fishery activities. The species are mainly caught by purse seine and gill net around the coastal area. Therefore, it is susceptible to overfishing, as indicated by declining annual landing for recent years, from 109,974 tons in 2013 to 78,631 tons in 2016 (Directorate General of Capture Fisheries 2017). Currently, the species is managed based on 11 distinct fisheries management areas (FMAs) (Regulation of Minister of Marine Affairs and Fisheries No. PER.01/MEN/2009). The subdivision was established according to the similarity of oceanography characteristics and dynamics in surrounding waters (Research Institute of Marine Research 2014) or known as the eco-region concept (Marini et al. 2017). In this concept, the fish species or group of species inhabiting within an FMA were assessed as a single stock. So far, the stock assessment in each FMA has not been conducted, specifically for Indian mackerel but rather species belonging to the small pelagic group instead. Then, various stock statuses have been assigned to each FMA (Decree of Minister of Marine Affairs and Fisheries No. 47/KEPMEN-KP/2016). This situation makes this species or group of species vulnerable to localize overfishing (e.g. in the FMA 573 that covered area between southern Java, Bali, and Nusa Tenggara waters) stated as over-exploited by indicating a high fishing pressure around the coastal zone. Therefore, an initiative to identify population structures that may contribute to the potential stock within FMA is urgently needed before assessing the stock status. This understanding is of substantial attention to establishing a management plan that ensures the harvest strategies are appropriately developed within Indonesia's Exclusive Economic Zone (EEZ).

Several studies have been taken to explain the condition of marine fish population structures within Indonesian waters, including morphometric meristic (Marini et al. 2017), genetic (Zamroni et al. 2017, 2016), parasite occurrence (Moore et al. 2019), and otolith shape (Wujdi et al. 2017). Only genetic approaches have been applied to investigate Indian mackerel population structures from different FMAs in Indonesia (Zamroni et al. 2017, 2016). Recently, otolith shape has been the most widely applied method of stock separation worldwide, specifically on the various species of mackerel (Moreira et al. 2019; Turan 2006; Vasconcelos et al. 2018), due to its ease of use, low cost, efficiency in labor time, and the wide availability of otolith archives. Otoliths result from continuous incremental growth of calcium carbonate $\left(\mathrm{CaCO}_{3}\right)$ structures; therefore, they are not reabsorbed, thus providing a permanent record of an individual's growth according to variability in the environment (Campana \& Neilson 1985).

The extensive use of otolith shape has also been linked with advances in image processing and computing technology. The otolith can be reconstructed efficiently using Fourier and Wavelet-based transformation; both are signal processing techniques commonly used for otolith remodeling. However, due to limited ability of Fourier transform for approximating the specific irregularities of otolith edges, the Wavelet transform has been proposed recently in otolith reconstruction (Christensen et al. 2018; Libungan et al. 2015; Parisi-Baradad et al. 2005; Tuset et al. 2019). Unlike the Fourier transform provides a function in the form of sines and cosines, which is local in frequency, the Wavelet transform is localized in both time and frequency (Gencay et al. 2001). Therefore, the otolith's shape can be determined precisely on a point-by-point basis to distinguish where variations have appeared. This benefit allows us to analyze a specific area of interest to detect specific changes of otolith outline (Libungan et al. 2015; Parisi-Baradad et al. 2005; Sadighzadeh et al. 2014a). Consequently, the present study intended to evaluate otolith shape for investigating population structures of Rastrelliger kanagurta. Variability of otolith shape between localities was examined through Wavelet transformation that may have implications for the sustainable management of the Indian mackerel fisheries.

\section{MATERIALS AND METHODS}

\section{SAMPLE COLLECTION}

A total of 159 Indian mackerel (R. kanagurta) were sampled at four fishing ports along the southern coast of Java and Bali, namely Palabuhanratu, Pacitan, Muncar, and Kedonganan (Figure 1). Samples were caught by one-day trip fishing gear to ensure the fish inhabited the surrounding waters representing the port-landing base. Species identification during field surveys is based on Muto et al. (2016) and White et al. (2013). Biological parameters were recorded during the field sampling, including fork length (FL) and body weight (W) of each fish were recorded to the nearest $0.1 \mathrm{~cm}$ and $0.1 \mathrm{~g}$, respectively. Sex was determined by visual examination of gonads. The sagittal otoliths were extracted using the gill method (Secor et al. 1992), washed, cleaned in distilled water, and then dried and stored in labeled plastic tubes. Fish sampling details are summarized in Table 1. 
The left side of sagittal otolith from each sample was placed on a plate with a dark background, rostrum pointed to the left, with the distal surface upwards and sulcus facing downwards. Then, high resolution of digital images at the same magnification of $6.3 \times$ was photographed under Leica M50 stereomicroscope, which connected with Leica IC80 HD digital camera. Images were stored in JPEG format (*.jpg). Image contrast, brightness, and transformation were manipulated to greyscale mode for each image using
ImageJ software (Schneider et al. 2012). In terms of otolith terminology, a nomenclature of morphological features, according to Smale et al. (1995) and Tuset et al. (2008), was followed (Figure 2). Overall, the otolith outline detection and statistical analyses were done in the software R 3.3.3 ( $\mathrm{R}$ Core Team 2016) using the packages ShapeR 0.1-5 (Libungan \& Palsson 2015a), Vegan 2.5-6 (Oksanen et al. 2013), Ipred 0.9-5 (Peters \& Hothorn 2015) and MASS 7.3-35 (Ripley et al. 2014).

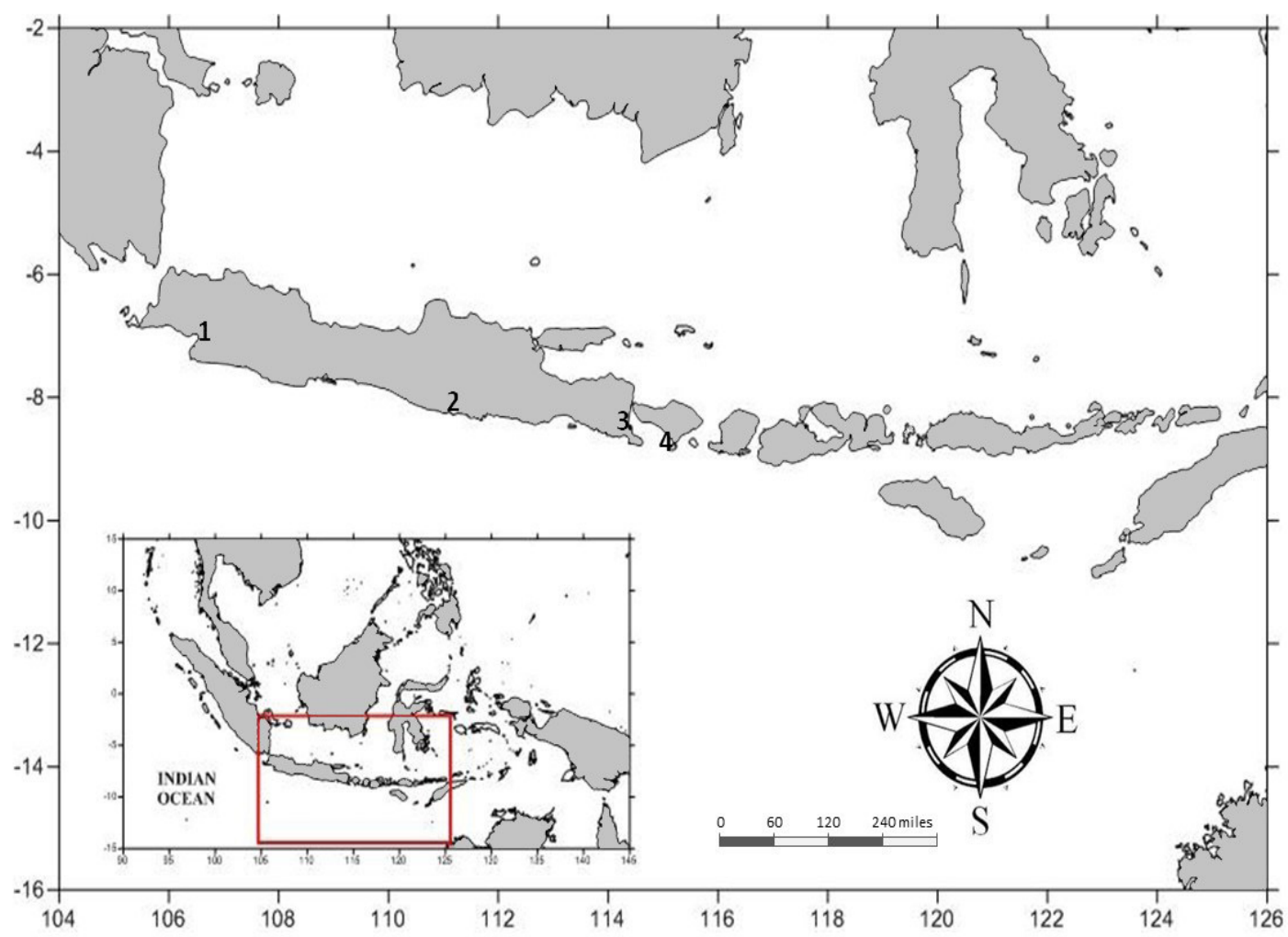

FIGURE 1. Sampling location for Indian mackerel (R. kanagurta) otolith: 1) Palabuhanratu, 2) Pacitan, 3) Muncar, and 4) Kedonganan

TABLE 1. Summary of otolith samples of Indian mackerel (R. kanagurta) that used in otolith shape analysis

\begin{tabular}{|c|c|c|c|c|c|}
\hline Localities & Sampling time & $\mathrm{n}$ & Gear & $\begin{array}{l}\text { Fork length }(\mathrm{cm}) \\
\quad \text { Mean } \pm \text { SD }\end{array}$ & $\begin{array}{c}\text { Weight }(\text { gram) } \\
\text { Mean } \pm \text { SD }\end{array}$ \\
\hline Palabuhanratu (PR) & April 2018 & 38 & Boat lift net & $\begin{array}{c}14.4-20.9 \\
(18.5 \pm 2.2)\end{array}$ & $\begin{array}{l}39.4-140.0 \\
(96.4 \pm 33.5)\end{array}$ \\
\hline Pacitan (CT) & April 2018 & 23 & Gill net & $\begin{array}{c}16.8-26.9 \\
(21.3 \pm 2.3)\end{array}$ & $\begin{array}{c}60.0-330.0 \\
(154.7 \pm 70.8)\end{array}$ \\
\hline Muncar (MC) & August 2016 & 54 & Boat lift net & $\begin{array}{l}19.0-26.0 \\
(22.6 \pm 1.7)\end{array}$ & $\begin{array}{c}106.7-329.9 \\
(202.5 \pm 54.3)\end{array}$ \\
\hline Kedonganan (KD) & July 2018 & 44 & Gillnet & $\begin{array}{l}15.2-28.0 \\
(20.4 \pm 4.9)\end{array}$ & $\begin{array}{c}54.0-401.0 \\
(169.9 \pm 133.4)\end{array}$ \\
\hline
\end{tabular}




\section{OTOLITH IMAGING AND SHAPE ANALYSIS}

The outline analysis was determined for each digital image of otolith using the ShapeR package followed the systematic procedure to eliminate the pixel noise (Libungan \& Palsson 2015a) in the R software ver. 3.3.3 (R Core Team 2016). A series of otolith morphometry parameters were obtained, namely otolith length (OL, in $\mathrm{mm}$ ), width (OW, in $\mathrm{mm})$, area $\left(\mathrm{OA}\right.$, in $\left.\mathrm{mm}^{2}\right)$, and perimeter (OP, in $\mathrm{mm}$ ) (see the Appendix; Figure 2). The $\mathrm{x}$ and $\mathrm{y}$ coordinate matrices of all otolith outlines are estimated based on the longest horizontal axis. Equally spaced radii were produced and drawn from the centroid of the otolith to the otolith outline. The distance of these radii defines as a univariate shape descriptor. The Wavelet coefficients were extracted from digital images of otolith based on the Wavelet transformation to the equally spaced radii using the Wavethresh package (Nason 2012). By applying 10 Wavelet levels, then 64 Wavelet coefficients, respectively, resulted in an accuracy rate of $98.5 \%$ (Libungan et al. 2015; Libungan \& Palsson 2015b). However, as an allometric growth was observed among the four populations of Indian mackerel, therefore the interaction between the Wavelet coefficients and the FL measurements was examined using a normalization technique based on regression by scaling the Wavelet coefficients with FL. When a significant interaction $(p<0.05)$ was observed, those coefficients were excluded from the analysis to eliminate the allometric effect on otolith shape (Libungan \& Palsson 2015b; Libungan et al. 2015; Lleonart et al. 2000; Longmore et al. 2010). A total of 8 Wavelet coefficients did not meet the assumptions, thus were omitted; meanwhile, the remaining coefficients were used for further statistical analysis.

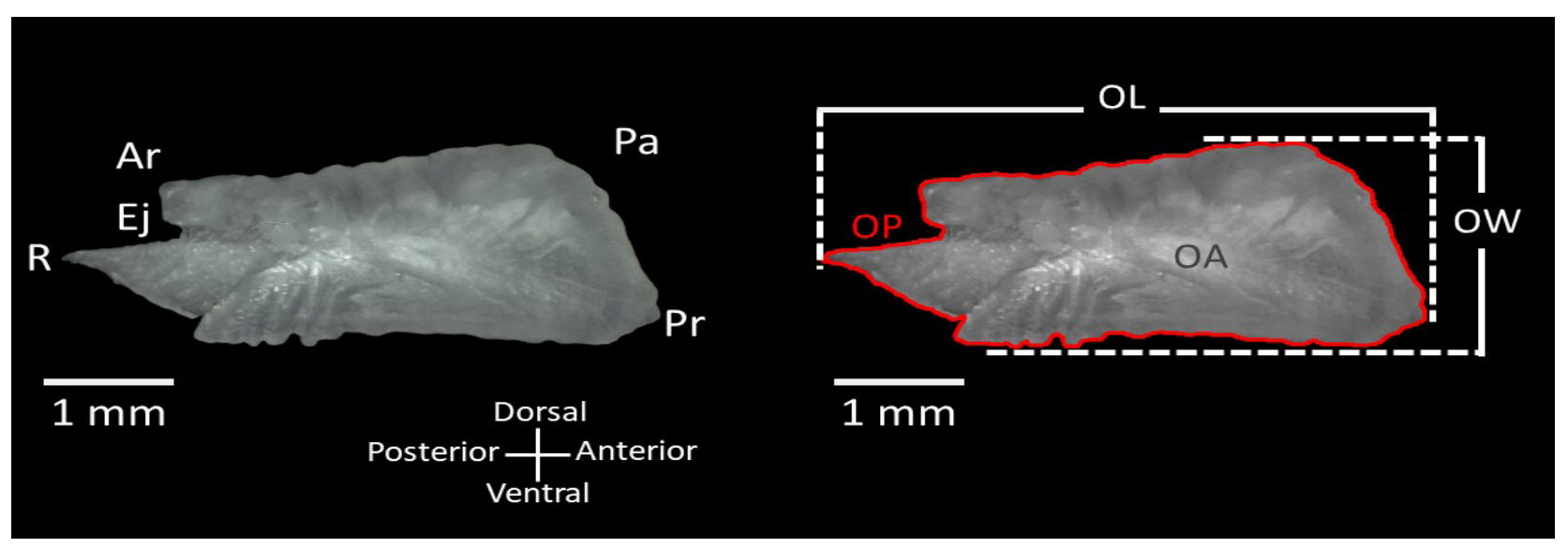

FIGURE 2. Otolith position for outline analysis with its morphological nomenclature, namely; (R) Rostrum, (Ar) Antirostrum, (Pr) Postrostrum, (Pa) Pararostrum, and (Ej) Excisura Major. A Delineated of otolith outline by using the ShapeR package shown as the red line to determine variation otolith morphometry among localities

\section{MEAN OTOLITH SHAPE ANALYSIS}

The mean of the otolith shape from each population was plotted into $\mathrm{x}$ and $\mathrm{y}$ matrix based on the normalized Wavelet coefficients to visually evaluate the variation of otolith shape among the populations (Figure 3). The Wavelet transformation provides more detailed information for approximating otoliths' edges (Libungan et al. 2015). It allows us to show more accurate detection of otolith morphological features indicating the most variation between populations. The mean of Wavelet coefficients from all pooled otoliths also was plotted against the angle of 0 to 360 degrees by the gplots package (Warnes et al. 2015) (Figure 4). Intraclass correlations were also calculated at the angle of otolith outlines representing the proportion of variation between groups. It provides more information about the partitioning of variations along with the otolith outlines to measure differences between populations.

\section{STATISTICAL ANALYSIS ANOVA-LIKE PERMUTATION TEST}

We used an analysis of variance (ANOVA)-like permutation test to the radii's length as a univariate shape descriptor to examine the differences between populations based on 1000 permutations. The test was 
done using the Vegan package (Oksanen et al. 2013) without normality requirement. The signification of otolith shape between males and females was also examined within each locality to recognize if there is a possibility of combining otolith shape from two sexes. Since there were no significant differences in otolith shape between males and females in all sampling sites ( $p>0.05$; Tabel 2). Therefore, both sexes from each sampling were combined for further analysis.

\section{CANONICAL ANALYSIS OF PRINCIPAL COORDINATES} (CAP)

To evaluate the otolith shape variation between populations, the mean of standardized Wavelet coefficients were imported into principal coordinates and subjected to the canonical analysis (CAP: Canonical Analysis of Principal coordinates) (Anderson \& Willis 2003). The result of CAP compared the mean of shape coefficient between populations according to the two discriminating axes CAP1 and CAP2, using the Vegan package's capscale function (Oksanen et al. 2013).

\section{LINEAR DISCRIMINANT ANALYSIS (LDA)}

The classification of the individual sample of otolith into groups was examined by a Linear Discriminant Analysis (LDA) on the standardized Wavelet coefficients. It was carried out using the leave-one-out crossvalidation procedure to show how precise otolith shapes can classify samples back to their origin. The classification of success rate was assessed using a crossvalidation estimation process between two populations alternately using the CV=TRUE argument in the errorest and lda function within the ipred and MASS package, respectively (Peters \& Hothorn 2015; Ripley et al. 2014).

\section{RESULTS}

\section{VARIATIONS OF THE MEAN OTOLITH SHAPES AMONG POPULATIONS BASED ON WAVELET COEFFICIENTS}

The mean Wavelet coefficients' reconstructed outlines were modeled as an overlay picture with 0 to $360^{\circ}$ angle to visualize variations in average otolith shapes between populations (Figure 3). In general, sagittal otoliths of Indian mackerel are oblong-elongated in shape, of medium thickness and the distal surface tends to be convex. The dorsal margin is slightly elevated, with lobes ending close to the Pararostrum $(\mathrm{Pa})$, while the ventral margin is generally concaved with several crenulations. Otoliths from Muncar (MC) tend to be wider on the Pararostrum
(Pa) and narrower on the ventral than those otoliths from Palabuhanratu (PR), Pacitan (CT), and Kedonganan (KD). All these attributes of the otolith shape were modeled using the Wavelet transform and demonstrated for the Indian mackerel populations' stock differentiation.

The mean otolith shape analysis based on the Wavelet coefficients showed a variation of the mean otolith shape between the geographically close populations. These were identified roughly as two different groups, i.e. MC-KD as group 1 and PR-CT as group 2. The differences were mainly detected along the Antirostrum (Ar) area and Excisura major (Ej) part. These differences were also confirmed quantitatively using the mean of Wavelet coefficient and intraclass correlation (ICC), indicating that the most variations occurred at approximately 160 $180^{\circ}$. These findings suggested that the area between Antirostrum (Ar) and Excisura major (Ej) was identified as the most varied among the populations (Figure 4). The intraclass correlations (ICC) peak at $130-140^{\circ}$ at the ventral edge. Further examination at the Antirostrum (Ar) and Excisura major (Ej) reveals that $\mathrm{KD}-\mathrm{MC}$ populations had overlapped between each other, while CT-PR populations are similar. At the Antirostrum (Ar), $\mathrm{KD}$ and MC populations' mean shape is in the outermost and overlapped together, reflecting a similarity as they have the farthest shape distance from the centroid. Otolith from $\mathrm{CT}$ and PR populations are similarly located in the innermost and their space is the closest to the centroid. The pattern was also similar at the Excisura major (Ej) part that KD and $\mathrm{MC}$ have the farthest space, while $\mathrm{CT}$ and PR in the innermost represent the closest space between the otolith's edge and the centroid.

\section{UNIVARIATE AND MULTIVARIATE ANALYSIS BETWEEN POPULATIONS}

The difference in the otolith shape between the four localities of Indian mackerel was also detected by an ANOVA-like permutation test using 1000 permutations. The result showed that a significant difference was detected between all populations $(p<0.001)$, except between Palabuhanratu (PR) and Pacitan (CT) (Table 3). Variations of otolith shape also are confirmed by the multivariate analysis. Using a canonical analysis of principal (CAP) based on the Wavelet coefficient, the two discrimination axes of CAP explained $95.6 \%$ of the variation among the four populations of $R$. kanagurta (CAP $1=70.3 \%$, CAP 2 $=25.3 \%$ ). Based on the CAP 1 axis, those otoliths from Pacitan (CT) and Palabuhanratu (PR) are similar, indicated by an overlap of the mean \pm standard error value of the canonical score of the Wavelet coefficient. Unlike CAP 1, 


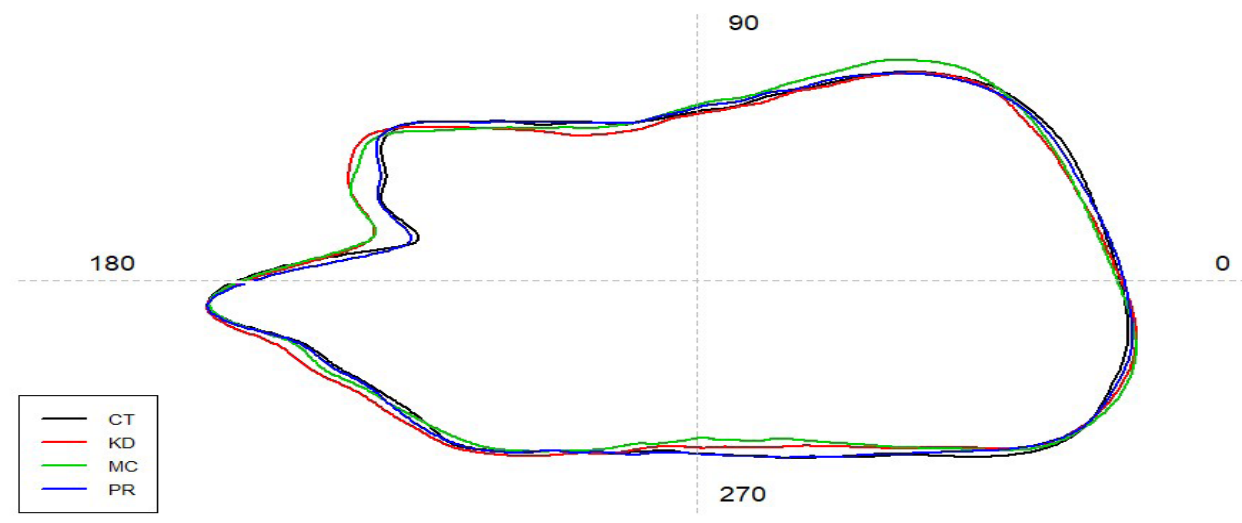

FIGURE 3. The average otolith shape is based on the Wavelet coefficients between four $R$. kanagurta populations. The numbers of $0,90,180$, and 270 correspond to angles in degrees $\left(^{\circ}\right)$ based on polar coordinates. The point obtained by the crossed-two coordinate axis is the central point of polar coordinates defined as the centroid

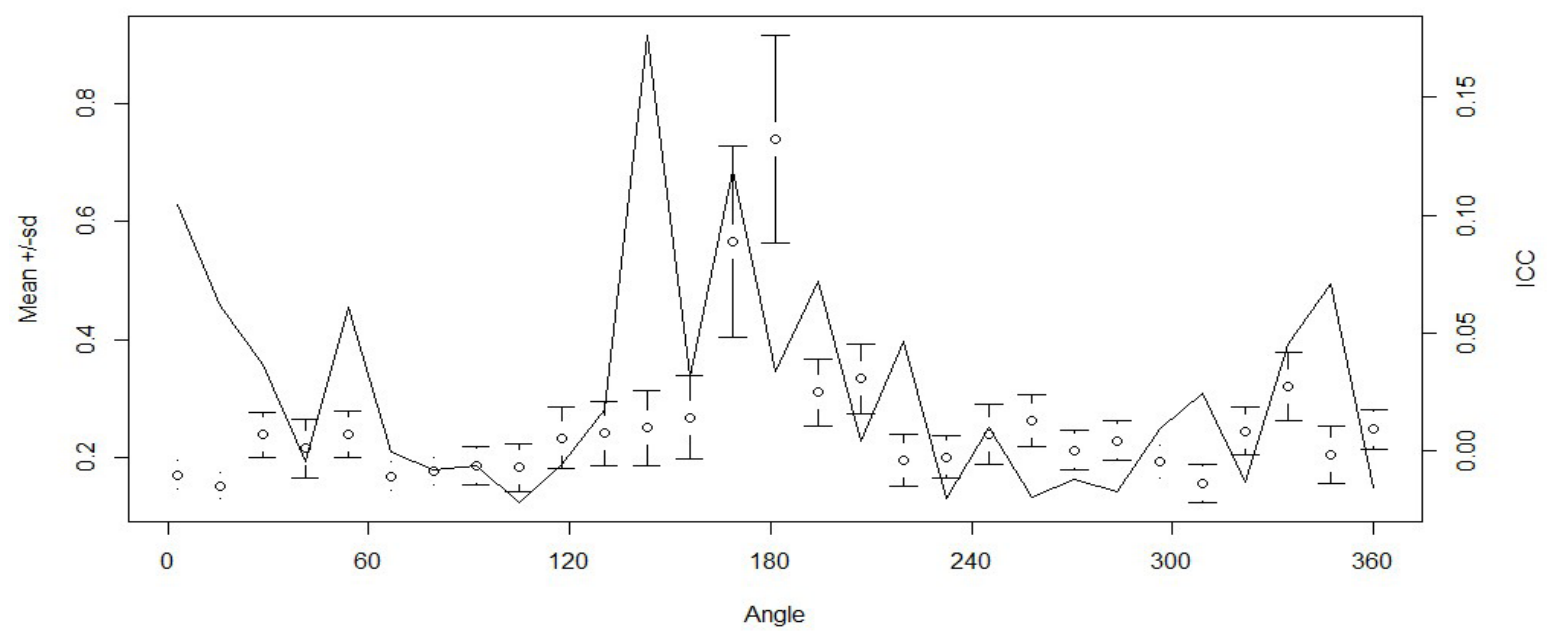

FIGURE 4. Mean and standard deviation (sd) of the Wavelet coefficients for all combined otolith from the four R. kanagurta populations and the intraclass correlation or ICC (solid black line). The horizontal axis shows the angle in degrees $\left(^{\circ}\right.$ ) as a unit connected to the otolith centroid's directional angle (see Figure 3)

when otoliths from Muncar (MC) and Kedonganan (KD) appeared imminently, CAP 2 axis demonstrated that otoliths from those localities slightly deviated from each other. In contrast, the rest of the otoliths from Palabuhanratu and Pacitan were overlapped (Figure 5).

TABLE 2. Otolith shape comparison between males and

females based on ANOVA-like permutation test using 1000 permutations

\begin{tabular}{ccccccc}
\hline Comparison & df & $\begin{array}{c}\text { Sum of } \\
\text { Square (SS) }\end{array}$ & F & P & Residual & \multicolumn{2}{c}{ Residual } \\
All populations & 3 & 2.903 & 1.4034 & 0.104 & 120 & 82.743 \\
PR & 1 & 0.404 & 0.6246 & 0.792 & 26 & 16.795 \\
CT & 1 & 0.584 & 0.8618 & 0.522 & 44 & 29.832 \\
MC & 1 & 0.467 & 0.701 & 0.689 & 28 & 18.632 \\
KD & 1 & 1.441 & 1.6053 & 0.115 & 22 & 19.742 \\
\hline
\end{tabular}


TABLE 3. Otolith shape differences between the four populations of $R$. kanagurta based on 1000 permutations

\begin{tabular}{|c|c|c|c|c|c|c|}
\hline Comparison & $\mathrm{df}$ & $\begin{array}{l}\text { Sum of } \\
\text { Square }\end{array}$ & $\mathrm{F}$ & $\mathrm{P}$ & $\begin{array}{c}\text { Residual } \\
\text { df }\end{array}$ & $\begin{array}{c}\text { Residual } \\
\text { SS }\end{array}$ \\
\hline All populations & 3 & 15.81 & 7.704 & $0.001 *$ & 155 & 106.020 \\
\hline PR vs CT & 1 & 1.163 & 1.244 & 0.233 & 59 & 55.151 \\
\hline PR vs KD & 1 & 9.543 & 9.355 & $0.001 *$ & 80 & 81.608 \\
\hline PR vs MC & 1 & 12.418 & 13.898 & $0.001 *$ & 90 & 80.417 \\
\hline CT vs MC & 1 & 10.158 & 11.444 & $0.001 *$ & 75 & 66.572 \\
\hline CT vs KD & 1 & 8.609 & 8.258 & $0.001 *$ & 65 & 67.763 \\
\hline MC vs KD & 1 & 6.558 & 6.767 & $0.001 *$ & 96 & 93.029 \\
\hline
\end{tabular}

${ }^{*} \mathrm{p}<0.05$ shows significant different

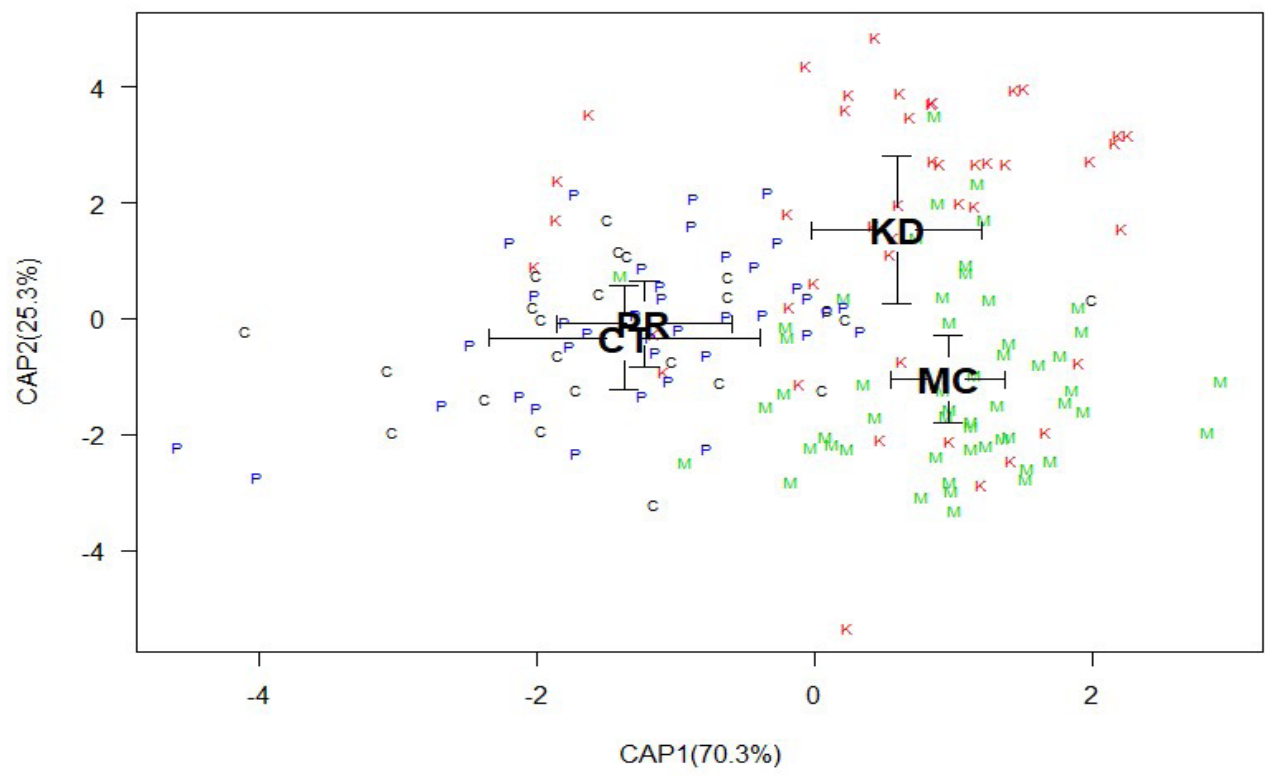

FIGURE 5. The cluster analysis plots from the four populations of R. kanagurta using Wavelet coefficients, calculated by Canonical analysis of Principal Coordinates (CAP). The interval surrounding the average canonical scores presents as standard error (mean \pm 1 standard error)

\section{SAMPLES CLASSIFICATION BACK TO THE ORIGIN}

The LDA test can classify individuals from four $R$. kanagurta populations back to their sample origin based on the Wavelet coefficient. In total, the otolith shape can differentiate samples among localities with $54.1 \%$ rate of classification success. The classification success rate was also observed between two populations with a leaveone-out cross-validation procedure. The classification success rate showed a high percentage among the groups that showed a significant difference in the ANOVA-like test and vice versa. The classification success between the Palabuhanratu and Pacitan, for which the ANOVA-like test was not significant, was only $44.26 \%$. In comparison, the highest classification success rate was identified between Palabuhanratu (PR) and Muncar (MC), with $82.61 \%$ where both locations are geographically separated (Table 4). 
TABLE 4. Summary of Linear Discriminant Analysis for the four populations of Indian mackerel (R. kanagurta) based on wavelet coefficient

\begin{tabular}{lcc}
\hline & \multicolumn{2}{c}{ Linear discriminant analysis } \\
\cline { 2 - 3 } Populations & Missclasification error & Total correct (\%) \\
\hline PR vs CT & 0.5082 & 44.26 \\
PR vs KD & 0.3415 & 71.95 \\
PR vs MC & 0.1413 & 82.61 \\
CT vs MC & 0.3247 & 72.72 \\
CT vs KD & 0.4627 & 50.75 \\
MC vs KD & 0.3776 & 57.14 \\
\hline
\end{tabular}

Overall classification success rate (cross-validated) 54.1\%

\section{DISCUSSION}

The population structure of Indian mackerel along the southern coast of Java and Bali was unknown prior to this study. The species or group of species caught within the same FMA have been considered and managed as a single stock. The present study demonstrated that $R$. kanagurta along southern Java and Bali showed variability in otolith shape. We demonstrated the suitability of the Wavelet transformation for reconstructing otolith outlines. The morphological of Antirostrum (Ar) and Excisura major $(\mathrm{Ej})$ were detected as the most significant contributors to the overall variation among populations.

Differences in otolith shape are stimulated by environmental and genetic factors (Campana \& Casselman 1993; Cardinale et al. 2004; Hüssy et al. 2016; Vignon \& Morat 2010). Some researchers have highlighted the variability in otolith morphology relatable with environmental factors (Campana 1999), such as salinity and temperature (Sadighzadeh et al. 2014b), food availability (Libungan et al. 2015), variations in life-history (Tuset et al. 2016), and growth rate variations (Campana \& Casselman 1993). Genetic factors that affected otolith growth from the juvenile to adult stages via regulation of the response to exogenous factors, e.g., the relationship of diet with crystal formation and protein deposition otoliths (Reichenbacher et al. 2009; Vignon \& Morat 2010). Variations in otolith shape among species may reflect differences in balance and hearing physiological functions, and such variations may have adaptive implications (Brophy et al. 2016). Intraand inter-specific variations in otolith shape have been associated with feeding behavior, swimming performance (Kishida et al. 2011), habitat preference (Volpedo \& Fuchs 2010; Volpedo et al. 2008), and trophic niche (Lombarte et al. 2010). For example, benthic fishes found in the bottom layer of water are characterized by thick, wide, and rounded otoliths. At the same time, pelagic species commonly have elongated otoliths with a well-developed rostrum (Bani et al. 2013).

The role of genetics was recognized as one of the main factors that regulate otolith shape, however, hard to explain. No genetic population studies or growth investigation were published from these fishing grounds, while differences in the otolith shape were found simultaneously. Differences in otolith shape between localities in this study are likely affected by the oceanographic features along the southern coast of JavaBali, which presumably contributed to feeding migration and larval dispersal. A seasonal pattern of upwelling was observed from June until October along the south coast of Java-Bali, which may develop from east to west (Kunarso et al. 2012). Upwelling events, which occur when a cold water mass moves to the surface, are characterized by markedly lower SST and a high concentration of chlorophyll- $a$, which is the leading indicator of primary productivity (Sartimbul et al. 2010). These events 
carry nutrient-rich water to the surface, supporting abundant phytoplankton and zooplankton (Hendiarti et al. 2004; Sartimbul et al. 2010). Increased chlorophyll-a concentrations and low temperature can lead to a high abundance of $R$. kanagurta (Nurdin et al. 2015). The upwelling intensity weakened along the western part of Java Island (Kuswardani \& Qiao 2014), leading to limited migration of pelagic fish from east to west. The upwelling intensity also fluctuated with environmental conditions that impacted the movement and abundance of small pelagic fishes (Hendiarti et al. 2005). It is associated with the El Nino-Southern Oscillation (ENSO) and Indian Ocean Dipole (IOD) (Amri et al. 2015), as well as monsoon season, blows in between the Indonesian and Australian waters (Sartimbul et al. 2010).

Another oceanographical feature of sea surface currents also plays a vital role in the larval dispersal of marine species. The circulation of the Indian Ocean, particularly in the surface layer, is controlled mainly by the monsoon, referred to as monsoon drift. The South Equatorial Current (SEC) dominantly flowed westward throughout the year (Ilahude 1975). At the same time, the smaller coastal current called the Java Coastal Current (JCC) or Southern Java Current (SJC) (Peng et al. 2014), flowed eastward along with coastal areas near Java Island during the northwest and first transition monsoons, from December to June (Ilahude 1975). The JCC is tilted toward Bali Strait waters during the northwest monsoon from December to April (Ilahude 1975), which may lead to mixing fish larvae around the Bali Strait area, reflected by a similar shape of those otoliths obtained from Muncar and Kedonganan. These currents are also crucial for the larval dispersal of the Indian mackerel, which shows a mixing population between Palabuhanratu and Pacitan as observed as non-significant by ANOVA-like test low classification success by LDA. However, this should be confirmed using tagging studies to improve the understanding regarding fish migration and movements around these waters. Upwelling and surface currents can significantly affect on the feeding behavior and growth rate of a species that may differ among areas. In turn, such factors influence otolith shape (Campana \& Neilson 1985).

As presented in this study, otolith shape analysis can be used to obtain scientific evidence to support sustainable fisheries management and conservation. The results indicate that Indian mackere from the southern coast of Java-Bali can be divided into two distinct populations. Despite the relatively lower rate of the overall classification success shown by LDA $(54.1 \%)$, the otolith shape analysis can complement other population markers, thus increasing the mixed-stock assessment accuracy. Recently, a holistic approach by combining multiple techniques is most recommended to distinguish the stock structure of a species more accurately than applying a single method (Barton et al. 2018). Therefore, combining otolith shape with other techniques would improve the robustness of the fine-scale management policies necessary to manage fisheries resources properly. Such a holistic approach could help investigate the complex aggregation of Indian mackerel in the central study area. Furthermore, environmental factors must be considered in future research on population structure and distribution. This method may be necessary to develop appropriate management strategies for mixedstock fisheries in the context of climate variability, especially for stocks in adjacent waters that are fished simultaneously by many fishers or countries at similar feeding grounds.

\section{CONCLUSION}

The present study shows that otolith shape analysis can distinguish Indian mackerel populations from the southern coast of Java-Bali. Our findings provided a new proposal on the stock structures of $R$. kanagurta, and underline the necessity of considering information about the variability of species characteristics in fisheries management strategies. This method could be used regularly to develop a fish spatial migration model for estimating the impact of population mixing on the stock level. Moreover, it can be an entry point to improve our understanding of population structures and connectivity of Indian mackerel. This work can be followed by investigating the life history aspect and population dynamics necessary to develop appropriate management strategies for sustainable fisheries.

\section{ACKNOWLEDGEMENTS}

We are sincerely grateful to the two anonymous reviewers for their valuable comments and suggestions that led to improvements in our manuscript. Raymon Rahmanov Zedta and Prawira Atmaja Rintar Pandapotan Tampubolon are thanked for field survey in Pacitan. We are also thanked to Sekar Kartika Ayu and Indrastiwi Pramulati for their effort in otolith image processing. This study was supported by the Ministry of Marine Affairs and Fisheries of Republic of Indonesia using national budget Number SP DIPA-032.11.1.660054/2016 and SP DIPA-032.12.2.403826/2018 in 2016 and 2018, respectively. 


\section{REFERENCES}

Amri, K., Suman, A., Irianto, H.E. \& Wudianto. 2015. Effects of dipole mode and el-nino events on catches of yellowfin tuna (Thunnus albacares) in the eastern Indian Ocean off west Java. Indonesian Fisheries Research Journal 21(2): 75-90.

Anderson, M.J. \& Willis, T.J. 2003. Canonical analysis of principal coordinates: A useful method of constrained ordination for ecology. Ecology 84(2): 511-525.

Arrafi, M., Azmi, A.M., Piah, R.M. \& Muchlisin, Z.A. 2016. Biology of Indian mackerel, Rastrelliger kanagurta (Cuvier, 1817) in the western waters of Aceh. Iranian Journal of Fisheries Science 15(3): 957-972.

Bani, A., Poursaeid, S. \& Tuset, V.M. 2013. Comparative morphology of the sagittal otolith in three species of south Caspian gobies. Journal of Fish Biology 82(4): 13211332.

Barton, D.P., Taillebois, L., Taylor, J., Crook, D.A., Saunders, T., Hearnden, M., Greig, A., Welch, D.J., Newman, S.J., Travers, M.J., Saunders, R.J., Errity, C., Maher, S., Dudgeon, C. \& Ovenden, J. 2018. Stock structure of Lethrinus laticaudis (Lethrinidae) across northern Australia determined using genetics, otolith microchemistry and parasite assemblage composition. Marine and Freshwater Research 69(4): 487501.

Brophy, D., Haynes, P., Arrizabalaga, H., Fraile, I., Fromentin, J.M., Garibaldi, F., Katavic, I., Tinti, F., Karakulak, F.S., Macias, D., Busawon, D., Hanke, A., Kimoto, A., Sakai, O., Deguara, S., Abid, N. \& Santos, M.N. 2016. Otolith shape variation provides a marker of stock origin for north Atlantic bluefin tuna (Thunnus thynnus). Marine and Freshwater Research 67(7): 1023-1036.

Campana, S.E. 1999. Chemistry and composition of fish otoliths: Pathways, mechanisms and applications. Marine Ecology Progress Series 188: 263-297.

Campana, S.E. \& Casselman, J.M. 1993. Stock discrimination using otolith shape analysis. Canadian Journal of Fisheries and Aquatic Sciences 50(5): 1062-1083.

Campana, S.E. \& Neilson, J.D. 1985. Microstructure of fish otoliths. Canadian Journal of Fisheries and Aquatic Sciences 42(5): 1014-1032.

Cardinale, M., Doering-Arjes, P., Kastowsky, M. \& Mosegaard, H. 2004 . Effects of sex, stock, and environment on the shape of known-age Atlantic cod (Gadus morhua) otoliths. Canadian Journal of Fisheries and Aquatic Sciences 61(2): 158-167.

Christensen, H.T., Riget, F., Backe, M.B., Saha, A., Johansen, T. \& Hedeholm, R.B. 2018. Comparison of three methods for identification of redfish (Sebastes mentella and $S$. norvegicus) from the Greenland east coast. Fisheries Research 201(1): 11-17.

Collette, B.B. \& Nauen, C.E. 1983. FAO Species Catalogue Vol. 2 Scombrids of the World: An Annotated and Illustrated Catalogue of Tunas, Mackerels, Bonitos and Related Species Know to Date. FAO Fisheries Synopsis 2 (125). Rome: FAO.
Das, I., Hazra, S., Bhattacharya, S., Das, S. \& Giri, S. 2016. A study on seasonal change in feeding habit, health status and reproductive biology of Indian Mackerel (Rastrelliger kanagurta, Cuvier) in coastal water of West Bengal. Indian Journal of Geo-Marine Sciences 45 (2): 254-260.

Directorate General of Capture Fisheries. 2017. Statistic Data of Capture Fisheries. Jakarta: Directorate General of Capture Fisheries, Ministry of Marine Affair and Fisheries.

Gencay, R., Selcuk, F. \&Whitcher, B. 2001. Differentiating intraday seasonalities through wavelet multi-scaling. Physica A 289(3-4): 543-556.

Hariati, T. \& Fauzi, M. 2011. Reproductive aspects of Indian mackerel Rastrelliger kanagurta (Cuv. 1817) of northern Aceh waters. Jurnal Iktiologi Indonesia 11(1): 47-53 (In Bahasa Indonesia)

Hendiarti, N., Suwarso, Aldrian, E., Amri, K., Andiastuti, R., Sachoemar, S. \& Wahyono, I.B. 2005. Seasonal variation of pelagic fish catch around Java. Oceanography 18(4): 112-123.

Hendiarti, N., Siegel, H. \& Ohde, T. 2004. Investigation of different coastal processes in Indonesian water using SeaWiFS data. Deep Sea Research Part II: Topical Studies in Oceanography 51(1-3): 85-97.

Hulkoti, S.H., Shivaprakash, S.M., Anjanayappa, H.N., Somashekara, S.R., Benakappa, S., Naik, A.S.K., Prasad, L.G. \& Kumar, J. 2013. Food and feeding habits of mackerel Rastrelling kanagurta (Cuvier) from Mangalore Region. Environment and Ecology 31 (2A): 672-675.

Hüssy, K., Mosegaard, H., Albertsen, C.M., Nielsen, E.E., Hansen, J.H. \& Eero, M. 2016. Evaluation of otolith shape as a tool for stock discrimination in marine fishes using Baltic Sea cod as a case study. Fisheries Research 174: 210-218

Ilahude, A.G. 1975. Seasonal features of the hydrology of the Bali Strait. Marine Research of Indonesia 15: 37-73.

Kishida, M., Kanaji, Y., Xie, S., Watanabe, Y., Kawamura, T., Masuda, R. \& Yamashita Y. 2011. Ecomorphological dimorphism of juvenile Trachurus japonicus in Wakasa Bay, Japan. Environmental Biology of Fishes 90(3): 301-315.

Kunarso, Hadi, S., Ningsih, N.S. \& Baskoro, M.S. 2012. Variability of temperature and chlorophyll-a in upwelling areas at various ENSO and IOD occurrence in the waters of south Java to Timor. Ilmu Kelautan - Indonesian Journal of Marine Science 16(3): 171-180 (In Bahasa Indonesia).

Kuswardani, R.T.D. \& Qiao, F. 2014. Influence of the Indonesian throughflow on the upwelling off the east coast of South Java. Chinese Science Bulletin 59(33): 4516-4523.

Libungan, L.A. \& Palsson, S. 2015a. ShapeR: Collection and analysis of otolith shape data. R package version 0.1-5. https://CRAN.R-project.org/package=shapeR.

Libungan, L.A. \& Palsson, S. 2015b. ShapeR: An R package to study otolith shape variation among fish populations. PLoS ONE 10(3): e0121102.

Libungan, L.A., Oskarsson, G.J., Slotte, A., Jacobsen, J.A. \& Palsson, S. 2015. Otolith shape: A population marker for 
Atlantic herring Clupea harengus. Journal of Fish Biology 86(4): 1377-1395.

Lleonart, J., Salat, J. \& Torres, G.J. 2000. Removing allometric effects of body size in morphological analysis. Journal of Theoretical Biology 205(1): 85-93.

Lombarte, A., Palmer, M., Matallanas, J., Gómez-Zurita, J. \& Morales-Nin, B. 2010. Ecomorphological trends and phylogenetic inertia of otolith sagittae in Nototheniidae. Environmental Biology of Fishes 89(3-4): 607-618.

Longmore, C., Fogarty, K., Neat, F., Brophy, D., Trueman, C., Milton, A. \& Mariani, S. 2010. A comparison of otolith microchemistry and otolith shape analysis for the study of spatial variation in a deep-sea teleost, Coryphaenoides rupestris. Environmental Biology of Fishes 89(3-4): 591605.

Marini, M., Suman, A., Farajallah, A. \& Wardiatno, Y. 2017. Identifying Penaeus merguiensis de man, 1888 stocks in Indonesian fisheries management area 573: A truss network analysis approach. AACL Bioflux 10(4): 922-935.

Moore, B.R., Lestari, P., Cutmore, S.C., Proctor, C. \& Lester, R.J.G. 2019. Movement of juvenile tuna deduced from parasite data. ICES Journal of Marine Science 76(6): $1-12$.

Moreira, C., Froufe, E., Vaz-Pires, P. \& Correia, A.T. 2019. Otolith shape analysis as a tool to infer the population structure of the blue jack mackerel, Trachurus picturatus, in the NE Atlantic. Fisheries Research 209: 40-48.

Muto, N., Alama, U.B., Hata, H., Guzman, A.M.T., Cruz, R., Gaje, A., Traifalgar, R.F.M., Kakioka, R., Takeshima, H., Motomura, H., Muto, F., Babaran, R.P. \& Ishikawa, S. 2016. Genetic and morphological differences among the three species of the genus Rastrelliger (Perciformes: Scombridae). Ichthyological Research 63(2): 275-287.

Nason, G. 2012. Wavethresh: Wavelets statistics and transforms, version 4.5. R package. http://CRAN.R-project.org/ package $=$ wavethresh

Nurdin, S., Mustapha, M.A., Lihan, T. \& Ghaffar, M.A. 2015. Determination of potential fishing grounds of Rastrelliger kanagurta using satellite remote sensing and GIS technique. Sains Malaysiana 44(2): 225-232.

Oksanen, J., Blanchet, F.G., Kindt, R., Legendre, P., Minchin, P.R., O'Hara, R.B., Simpson, G.L., Solymos, P., Stevens, M.H.H. \& Wagner, H. 2013. Vegan: Community Ecology Package, Version 2.0-7. R Package. http://CRAN.R-project. org $/$ package $=$ vegan $/$.

Oktaviani, D., Supriatna, J., Erdmann, M. \& Abinawanto, A. 2014. Maturity stages of Indian mackerel Rastrelliger kanagurta (Cuvier, 1817) in Mayalibit Bay, Raja Ampat, West Papua. International Journal of Aquatic Science 5(1): 67-76.

Parisi-Baradad, V., Lombarte, A., Garcia-Ladona, E., Cabestany, J., Piera, J. \& Chic, O. 2005. Otolith shape contour analysis using affine transformation invariant wavelet transforms and curvature scale space representation. Marine and Freshwater Research 56(5): 795-804.
Peng, S., Qian, Y.K., Lumpkin, R., Du, Y., Wang, D. \& Li, P. 2014. Characteristics of the near-surface currents in the Indian Ocean as deduced from satellite-tracked surface drifters. Part I: Pseudo-eulerian statistics. Journal of Physical Oceanography 45(2): 441-458.

Peters, A. \& Hothorn, T. 2015. Ipred: Improve predictors $\mathrm{R}$ package version 0.9-5. https://cran.r-project.org/ package $=$ ipred

R Core Team. 2016. R: A language and environment for statistical computing. R Foundation for Statistical Computing. Vienna, Austria. Version 3.3.3. https://www.r-project.org/.

Reichenbacher, B., Feulner, G.R. \& Schulz-Mirbach, T 2009. Geographic variation in otolith morphology among freshwater populations of Aphanius dispar (Teleostei, Cyprinodontiformes) from the southeastern Arabian Peninsula. Journal of Morphology 270(4): 469-484.

Research Institute of Marine Research. 2014. Potency and Utilization Level of Fish Resources in the Fisheries Management Areas of the Republic of Indonesia (WPP RI). Jakarta: Ref Graphika.

Ripley, B., Venables, B., Bates, D.M., Hornik, K., Gebhardt, A. \& Firth, D. 2014. MASS: Support Functions and Datasets for Venables and Ripley's MASS ( ${ }^{\text {th }}$ edition, 2002), Version 7.3-35. https://cran.r-project.org/package=MASS

Sadighzadeh, Z., Otero-Ferrer, J.L., Lombarte, A., Fatemi, M.R. \& Tuset, V.M. 2014b. An approach to unraveling the coexistence of snappers (Lutjanidae) using otolith morphology. Scientia Marina 78(3): 353-362.

Sadighzadeh, Z., Valinassab, T., Vosugi, G., Motallebi, A.A., Fatemi, M.R., Lombarte, A. \& Tuset, V.M. 2014a. Use of otolith shape for stock identification of John's snapper, Lutjanus johnii (Pisces: Lutjanidae), from the Persian Gulf and the Oman Sea. Fisheries Research 155: 59-63.

Sartimbul, A., Nakata, H., Rohadi, E., Yusuf, B. \& Kadarisman, H.P. 2010. Variations in chlorophyll-a concentration and the impact on Sardinella lemuru catches in Bali Strait, Indonesia. Progress in Oceanography 87(1-4): 168-174.

Schneider, C.A., Rasband, W.S. \& Eliceiri, K.W. 2012. NIH Image to ImageJ: 25 years of image analysis. Nature Methods 9(7): 671-675.

Secor, D.H., Dean, J.M. \& Laban, E.H. 1992. Otolith removal and preparation for microchemical examination. In Otolith Microstructure Examination and Analysis - Canadian Special Publication of Fisheries and Aquatic 117, edited by Stevenson, D.K. \& Campana, S.E. Ottawa: Department of Fisheries \& Oceans. pp. 19-57.

Smale, M.J., Watson, G. \& Hecht, T. 1995. Otolith Atlas of Southern African Marine Fishes. Grahamstown: J.L.B. Smith Institute of Ichthyology.

Turan, C. 2006. The use of otolith shape and chemistry to determine stock structure of Mediterranean horse mackerel Trachurus mediterraneus (Steindachner). Journal of Fish Biology 69: 165-180.

Tuset, V.M., Jurado-Ruzafa, A., Otero-Ferrer, J.L. \& Santamaria, M.T.G. 2019. Otolith phenotypic variability of the blue jack 
mackerel, Trachurus picturatus, from the Canary Islands (NE Atlantic): Implications in its population dynamic. Fisheries Research 218: 48-58.

Tuset, V.M., Otero-Ferrer, J.L., Gomez-Zurita, J., Venerus, L.A., Stransky, C., Imondi, R., Orlov, A.M., Ye, Z., Santschi, L., Afanasiev, P.K., Zhuang, L., Farre', M., Love, M. \& Lombarte, A. 2016. Otolith shape lends support to the sensory drive hypothesis in rockfishes. Journal of Evolutionary Biology 29(10): 2083-2097.

Tuset, V.M., Lombarte, A. \& Assis, C.A. 2008. Otolith atlas for the western Mediterranean, north and central eastern Atlantic. Scientia Marina 72(S1): 7-198.

Vasconcelos, J., Vieira, A.R., Sequeira, V., Gonzalez, J.A., Kaufmann, M. \& Gordo, L.S. 2018. Identifying populations of the blue jack mackerel (Trachurus picturatus) in the Northeast Atlantic by using geometric morphometrics and otolith shape analysis. Fishery Bulletin 116(1): 81-92.

Vignon, M. \& Morat, F. 2010. Environmental and genetic determinant of otolith shape revealed by a non-indigenous tropical fish. Marine Ecology Progress Series 411: 231241.

Volpedo, A.V. \& Fuchs, D.V. 2010. Ecomorphological patterns of the lapilli of Paranoplatense Siluriforms (South America). Fisheries Research 102: 160-165.

Volpedo, A.V., Tombari, A.D. \& Echeverría, D.D. 2008. Ecomorphological patterns of the sagitta of Antarctic fish. Polar Biology 31(5): 635-640.

Warnes, G.R., Bolker, B., Bonebakker, L., Gentleman, R., Liaw, W.H.A., Lumley, T., Maechler, M., Magnusson, A., Moeller, S. \& Schwartz, M. 2015. gplots: Various R programming tools for plotting data. $\mathrm{R}$ package version 2.17 . 0. http:// cran.r-project.org $/$ package $=$ gplots.

White, W.T., Last, P.R., Dharmadi, Faizah, R., Chodrijah, U., Prisantoso, B.I., Pogonoski, J.J., Puckridge, M. \& Blaber, S.J.M. 2013. Market Fishes of Indonesia (Jenis-jenis Ikan di Indonesia). ACIAR Monograph No. 155. Canberra, Australia: Australian Centre for International Agricultural Research (ACIAR).
Wujdi, A., Setyadji, B. \& Nugroho, S.C. 2017. Stock structure identification of skipjack tuna (Katsuwonus pelamis Linnaeus, 1758) in Indian Ocean (Indonesian territory of FMA 573) using otolith shape analysis. Jurnal Penelitian Perikanan Indonesia 23(2): 77-88 (in Bahasa Indonesia).

Zamroni, A., Suwarso \& Kuswoyo, A. 2017. Genetic variation of Indian mackerel, Rastrelliger kanagurta (Cuvier, 1817) in the waters of eastern Indonesia. Bawal Widya Perikanan Tangkap 9(2): 123-131.

Zamroni, A., Suwarso \& Mardlijah, S. 2016. Populations genetic of Indian mackerel (Rastrelliger kanagurta Cuvier, 1817) in west Sumatera, Malacca Strait, and South China Sea. Jurnal Penelitian Perikanan Indonesia 22(1): 1-8.

\section{Arief Wujdi*}

International Graduate Program of Fisheries Science

Pukyong National University

Busan, 48513

South Korea

\section{Arief Wujdi*}

Research Institute for Tuna Fisheries

Denpasar, Bali, 80223

Indonesia

Han Ju Kim \& Chul Woong Oh

Department of Marine Biology

Pukyong National University

Busan, 48513

South Korea

*Corresponding author; email: ariefwujdi@kkp.go.id

Received: 12 January 2021

Accepted: 16 May 2021

Appendix. The value of mean \pm standard deviation for otolith morphometry parameters of the Indian mackerel from Palabuhanratu (PR), Pacitan (CT), Muncar (MC), and Kedonganan (KD)

\begin{tabular}{lcccc}
\hline & \multicolumn{4}{c}{ Mean \pm sd } \\
\cline { 2 - 5 } Morphometry parameters & PR & CT & MC & KD \\
\hline Otolith area $\left(\mathrm{mm}^{2}\right)$ & $5.430 \pm 1.272$ & $6.571 \pm 1.344$ & $7.563 \pm 1.262$ & $6.172 \pm 3.07$ \\
Otolith length $(\mathrm{mm})$ & $4.131 \pm 0.504$ & $4.549 \pm 0.484$ & $4.967 \pm 0.419$ & $4.344 \pm 1.083$ \\
Otolith width $(\mathrm{mm})$ & $1.842 \pm 0.266$ & $2.038 \pm 0.239$ & $2.199 \pm 0.208$ & $1.909 \pm 0.54$ \\
Otolith perimeter $(\mathrm{mm})$ & $10.334 \pm 1.463$ & $11.466 \pm 1.437$ & $12.303 \pm 1.199$ & $10.823 \pm 3.170$ \\
\hline
\end{tabular}

